\title{
Metformin Protects the Skeletal Muscle Glycogen Stores Against Alterations Inherent to Functional Limitation
}

\author{
Paula Lima Bosi * , Gabriel Delfino Borges ${ }_{2}^{2}$, João Luiz Quagliotti Durigan ${ }^{2}$, Karina Maria \\ Cancelliero and Carlos Alberto da Silva \\ ${ }^{1}$ Rua Maestro Arthur Bosmans, 55 - Apto 1002; Belvedere; 30320-680; plbosi@terra.com.br; Belo Horizonte - MG \\ - Brasil. ${ }^{2}$ Departamento de Fisioterapia; Universidade Metodista de Piracicaba - UNIMEP; Piracicaba - SP - \\ Brasil
}

\begin{abstract}
The aim of this study was to evaluate the glycogen content $(G C)$ of the rat hind limb muscles submitted to joint immobilization, either associated with metformin treatment (M, 1,4mg.ml-1) or not. In the metformin group, there was a significant increase in the GC (soleus - S 65\%, white gastrocnemius - WG 30.5\%, red gastrocnemiusRG31.7\%, extensor digitorum longus - EDL 44\%, tibialis anterior- TA 77.4\%). The immobilization significantly reduced the GC (S 31.6\%, WG 56.6\%, RG 39.1\%, ELD 41.7\%, TA 45.2\%) and weight (S 34.2\% and ELD 27\%), whereas in the group immobilized with the metformin, there was an increase in the GC of all the muscles $(S 177 \%$, WG 290\%, RG 172\%,ELD 47\%, TA 217\%), in addition to minimizing the weight loss of S (29.6\%) and ELD $(27.8 \%)$.
\end{abstract}

Key words: Muscle disuse, metformin, skeletal muscle, rehabilitation

\section{INTRODUCTION}

The muscle plasticity is the inherent capacity of the skeletal muscle to adapt to different stimuli. Multiple situations can promote these changes, surch as muscle disuse models, hormonal alterations, nutrition, neuromuscular electrical stimulation, among others deserve emphasis (Salvini, 2000). In this regard, it is known that the muscular hypotrophy induced by the muscle disuse occurs in association with the orthopedic diseases, such as immobilization in the treatment of fractures, chronic osteoarthritis, and in the treatment with glucocorticoids, or in the situations of maintenance by the prolonged bed rest (Reardon et al., 2001).
The muscle disuse produced by the conditions of prolonged inactivity, limb immobilization or microgravity, induces a condition of insulin resistance in the skeletal muscle, thus increasing its catabolic state (Ploug et al., 1995). Alterations in the insulin signaling pathways are found in the periods of the muscle disuse and immobilization, generating changes in glucose uptake, but the exact mechanism by which this occurs has not yet been clarified (Hirose et al., 2000).

It has been reported that the reduction in the neuromuscular junction activity caused by the forced inactivity or muscle disuse promotes a reduction in the effectiveness of the insulin signaling pathways, in the GLUT4 population, as well as in its genetic expression, compromising energy homeostasis and speeding up the

\footnotetext{
${ }^{*}$ Author for correspondence
} 
development of insulin resistance (Fushiki et al., 1991; Henriksen et al., 1991). As regards the phosphagenic glycogen content, it was demonstrated that during the immobilization, these energy substrates decrease slightly or remain unaltered (Booth and Sneider, 1979). Cancelliero et al. (2004) studied the rat hindlimb immobilization with the acrylic resin orthosis for a period of seven days, keeping the ankle in a neutral position and found that the glycogen content was significantly diminished by the muscle disuse. Moreover, a significant reduction was noted in the muscular weight and the fiber area, and an increase in the area occupied by the connective tissue (Durigan et al., 2006).

With the aim of minimizing the events set off by the muscle disuse, several techniques have been used, in an endeavor to improve the homeostatic conditions of the muscle fibers, with emphasis on the neuromuscular electrical stimulation (ES) drugs such as, clembuterol and supplements, vanadil sulphate, creatine, glutamine and CGT (creatine, glutamine, taurine) (Cancelliero et al., 2004; ALBINO Albino Junior et al., 2004; Delfino et al., 2006; Silva and Cancelliero, 2006). Guanidine metformin is used in the clinical therapy as an antibacterial, antiviral, antiinflammatory and hypotensive agent, histamine receptor antagonist, inducer of the alteration in the neuronal excitability linked to $\mathrm{Na}^{+}$channels, and inducer of the alteration in the release of neurotransmitters (Schafer, 1983). It has been reported that metformin can activate the insulin action mechanism, increasing the activity of its receptor, leading to translocation of the glucose transporters (GLUT4) to the plasmatic membrane of the skeletal muscles (Howlett and Bailey, 1999). The presence of insulin is, however, necessary for metformin to act. Therefore, this drug potentiates insulin action, prevents the development of insulin resistance, and favors glycogen synthesis in different tissues, including muscular tissue (Matthei and Greten, 1991).

In view of the above observations, the aim of this work was to evaluate the effect of metformin on rat hindlimb muscles with to joint immobilization with the ankle in the neutral position for seven days.

\section{MATERIAL AND METHODS}

Male Wistar rats (3 to 4 months old, 250-300g) were maintained in the controlled vivarium conditions with free access to the food and water and treated in accordance with the recommendations of the Guide on the care and use of the laboratory animals (1996) and approved by the Animal Ethics Committee (protocol 03/06). The animals were placed in the groups of 3 rats per cage $(40 \mathrm{x} 30 \mathrm{~cm})$ and submitted to a photoperiodic cycle of $12 \mathrm{~h}$ light/dark and controlled temperature $\left(23^{\circ} \mathrm{C} \pm 2\right)$. The animals were divided into four groups $(n=6)$ : control, immobilized, treated with metformin and immobilized treated with metformin for seven days. To prepare the orthoses, the rats were anesthetized with sodium pentobarbital $(40 \mathrm{mg} / \mathrm{kg}$ weight) and their left hindlimbs were immobilized with the acrylic resin models. The immobilization model used was proposed by Silva et al. (2006), characterized by the acrylic resin model that maintains the ankle joint immobilized in the neutral position (Fig 1). 


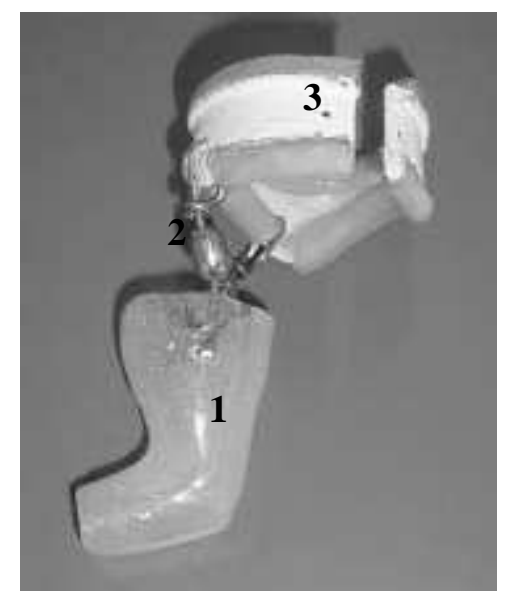

Figure 1 - Orthosis in the neutral ankle position, consisting of an acrylic resin model (1), lateral rotators (2) and an abdominal belt (3).

The groups treated with metformin received the substance diluted in water in the concentration from $1.4 \mathrm{mg} / \mathrm{mL}^{-1}$ (Guirro et al., 2004). After the experimental period, the rats were anesthetized with sodium pentobarbital ( $40 \mathrm{mg} / \mathrm{kg}$ weight) and after forty minutes, $0.25 \mathrm{ml}$ of the blood samples were collected for the blood glucose level analyses by glucometer (ACCU CHECK $^{\circledR}$ ). Other analyses performed were: glycogen content of the soleus (S), extensor digitorum longus (EDL), white gastrocnemius (WG), red gastrocnemius (RG), and tibialis anterior (TA) muscles, besides the evaluation of the weight of $\mathrm{S}$ and EDL.To determine the muscle glycogen, Siu et al. (1970) method was used. The values were expressed in $\mathrm{mg} / 100 \mathrm{mg}$ of wet weight. The statistical analysis was initially performed by the KolmogorovSmirnov normality test and the homoscedasticity test (Barlett criterion) followed by the parametric methodology of ANOVA and Tukey tests. The significance level was $p<0.05$ for all the analyses.

\section{RESULTS}

The blood glucose level of the rats did not change in any of the groups $(\mathrm{p}>0.05$, Table 1$)$, remaining at normal levels. The immobilization promoted significant reduction $(\mathrm{p}<0.05)$ in the glycogen content $(\mathrm{mg} / 100 \mathrm{mg})$ on $31.6 \%$ in $\mathrm{S}, 56.6 \%$ in WG, $39 \%$ in RG, $41.7 \%$ in EDL and $45.2 \%$ in TA (Table 2). Moreover, significant reduction $(\mathrm{p}<0.05)$ was observed in relation to the muscular weight $(\mathrm{mg})$ represented by $34 \%$ in $\mathrm{S}$ and $27 \%$ in ELD (Table 2) when compared with control group. The metformin treatment promoted significant increase $(p<0.05)$ in the glycogen content represented by $65 \%$ in $\mathrm{S}, 30.5 \%$ in $\mathrm{WG}, 31.7 \%$ in $\mathrm{RG}, 44 \%$ in EDL and $77.4 \%$ in TA, and did not promote significant increase $(p>0.05)$ in the weight of $\mathrm{S}$ and EDL (Table 2 and 3) when compared with the control group. In the immobilized group treated with metformin, there was a significant increase $(p<0.05)$ in the glycogen content in all the analyzed muscles, including the S (177\%), WG (290\%), RG (172\%), ELD (47\%) and TA $(217 \%)$ as shown in Table 1 . Moreover, the drug minimized the reduction of the muscular weight in the S muscle by $29.6 \%$ and in the EDL by $27.8 \%$ (Table 3 ) when compared with the immobilized group.

Table 1 - Blood glucose level (mg/dL) of the control (C), immobilized (I), treated with metformin (M) and immobilized treated with metformin $(\mathrm{I}+\mathrm{M})$ groups. The values represent mean \pm sem, $\mathrm{n}=6, \mathrm{p}>0.05$.

\begin{tabular}{lcccc}
\hline $\mathbf{C}$ & $\mathbf{I}$ & $\mathbf{M}$ & $\mathbf{I + \mathbf { M }}$ \\
\hline Blood Glucose & $89.5 \pm 1.2$ & $92.41 \pm 5.1$ & $86.8 \pm 4.2$ & $84.3 \pm 2.2$ \\
\hline
\end{tabular}


Table 2 - Muscle glycogen content (mg/100mg) of the soleus (S), white gastrocnemius (WG), red gastrocnemius $(\mathrm{RG})$, extensor digitorum longus (EDL) and tibialis anterior (TA) of the control (C), immobilized (I), treated with metformin $(\mathrm{M})$ and immobilized treated with metformin $(\mathrm{I}+\mathrm{M})$ groups. The values represent mean $\pm \operatorname{sem}, \mathrm{n}=6 \mathrm{p}<0.05$ * compared with control and ${ }^{\#}$ compared with immobilized.

\begin{tabular}{lcccc}
\hline Muscles & $\mathbf{C}$ & $\mathbf{I}$ & $\mathbf{M}$ & $\mathbf{I + M}$ \\
\hline $\mathrm{S}$ & $0.38 \pm 0.03$ & $0.26 \pm 0.02^{*}$ & $0.63 \pm 0.07^{*}$ & $0.72 \pm 0.21^{\#}$ \\
WG & $0.46 \pm 0.02$ & $0.20 \pm 0.02^{*}$ & $0.6 \pm 0.06^{*}$ & $0.78 \pm 0.12^{\#}$ \\
RG & $0.41 \pm 0.01$ & $0.25 \pm 0.03^{*}$ & $0.54 \pm 0.04^{*}$ & $0.68 \pm 0.15^{\#}$ \\
EDL & $0.36 \pm 0.03$ & $0.21 \pm 0.02^{*}$ & $0.63 \pm 0.07^{*}$ & $0.31 \pm 0.03^{\#}$ \\
TA & $0.31 \pm 0.03$ & $0.17 \pm 0.02^{*}$ & $0.55 \pm 0.09^{*}$ & $0.54 \pm 0.07^{\#}$ \\
\hline
\end{tabular}

Table 3. Muscle weight (mg) of the soleus (s) and extensor digitorum longus (EDL) of the control (C), immobilized (I), treated with metformin $(\mathrm{M})$ and immobilized treated with metformin $(\mathrm{I}+\mathrm{M})$ groups. The values represent mean \pm sem, $n=6, p<0.05$. *compared with control and ${ }^{\#}$ compared with immobilized.

\begin{tabular}{lcccc}
\hline Muscles & $\mathbf{C}$ & $\mathbf{I}$ & $\mathbf{M}$ & $\mathbf{I + M}$ \\
\hline $\mathrm{S}$ & $123.5 \pm 2.1$ & $81.3 \pm 1.89^{*}$ & $134.5 \pm 3.89$ & $105.4 \pm 7.53^{\#}$ \\
$\mathrm{EDL}$ & $120.6 \pm 8.5$ & $88.1 \pm 7.8^{*}$ & $128.5 \pm 5.1$ & $112.5 \pm 7.6^{\#}$ \\
\hline
\end{tabular}

\section{DISCUSSION}

The events set off by the functional limitation could be morphological, biochemical and physiological and have been the focus of many studies (Vanderborne et al., 1998, Mussacchia et al., 1988, Zarzhevsky et al., 1999). In the muscle atrophy induced by the disuse, the fast muscle fibers change to slow and the capacity to generate force and energy substrate decreases. These adaptations were observed under various conditions, such as immobilization, hind limb suspension and microgravity (Aoki, 2004).

The development of insulin resistance in the skeletal muscle is of extreme importance in the muscular disuse period. In this context, Hirose et al. (2000) studied the insulin signaling pathway in the rats that had the left limb immobilized by the knee and ankle fixation at $90^{\circ}$ for seven days. A reduction was observed in the transduction of the intracellular signal stimulated by insulin, suggesting deficit in the IR (insulin receptor) activation and in the molecules activated by this, including the phosphorylation of the IRS-1 (insulin receptor substrate-1) and PI3-K (phosphatidyl inositol 3 kinase) activation, indicating that insulin resistance can also be set off in the immobilization. This could explain the results of the decreased glycogen in the present study, as it was one of the mechanisms activated by the PI3-K subunit. Thus, the need to preserve the effectiveness of the PI3-K pathway is emphasized, because of its importance in the glucose metabolism of the skeletal muscle, as it is known that it promotes the translocation of GLUT (glucose transporter), and lipid, protein and glycogen synthesis (Wicox, 2005).

In this study it was observed that the muscular glycogen content of the white fibers (type II) was more affected, corroborating the findings of Herbisson et al. (1978), Jaffe et al. (1979) and McDougall et al. (1980). It could be, furthermore, emphasized that in addition to the metabolic alterations, there was also weight reduction, which could suggest a reduction in the number and/or size of muscle fibers, characteristic of a negative protein turnover (Mitch and Goldberg, 1996, Zdanowicz and Teihberg, 2003).

It is known that the metabolic homeostasis of the organism can be affected by different conditions, such as stress, physical activity, or drugs that cause modifications in the storage and mobilization of the energy reserves. As regards the drugs, it is known that the oral anti-hyperglycemic agent, metformin, potentiates the action of the insulin, prevents the development of insulin 
resistance and favors the glycogen synthesis in different tissues (Matthei et al., 2000; Bailey, 2005). Furthermore, other authors showed an increase in the activity in tissue sensitivity to insulin and that this increase was related to some mechanisms, for example, increase in the tyrosine kinase insulin receptor activity (Pryor et al.,2000). In this study, in the groups treated with the metformin, significant increase was observed in the glycogen content of all the analyzed muscles. This increase in glycogen synthesis and reduced glycogen mobilization could be explained by the potential of the glucose uptake, due to the effect of metformin at the level subsequent to insulin receptor linking, and also to its capacity to promote the translocation of the glucose transporters GLUT4 to the plasmatic membrane of the skeletal muscles (Howlett and Bailey, 1999; Doustou and Gerich, 2001). Guirro et al. (2004) also observed improvement in the metabolic profile of the muscles submitted to denervation after metformin treatment $\left(1.4 \mathrm{mg} \cdot \mathrm{ml}^{-1}\right)$ for 30 days, being represented by an increase in the glycogen content of $34.61 \%$ in the soleus, $91.30 \%$ in the red gastrocnemius and $166.66 \%$ in the white gastrocnemius.

As yet, there is no report in the literature of efficient treatment to prevent or to hinder the deleterious effects inherent to the muscle disuse, however, with some of the signaling pathways related to the muscular hypotrophy being identified, and with the advances of the pharmaceutical industry, some treatments are being used with the intention of minimizing the effects resulting from the muscle disuse (Glass, 2003).

In the groups treated with the metformin during the immobilization period, the energy profile of the skeletal musculature was found to be enhanced in all the analyzed muscles. It is important to emphasize that metformin did not present predilection for the action according to fiber type, therefore the increase in the glycogen content took place uniformly among the muscles. The increase in weight and glycogen content could be explained by the cross-talk capacity of biguanide with the insulin pathways in insulin resistant tissues, where it promoted an increase in the tyrosine phosphorylyzation of the IR and IRS-1, and in PI3-K pathway activity, associated with IRS-1 (Matthei et al., 2000). Other authors observed these effects of metformin on the glycogenic metabolism and $[3 \mathrm{H}]$-2-deoxiglicose transport in the insulin resistant soleus muscle in the animal models, such as mice KK or rats Sprague-Dawley (Reddi and Jyothirmayi, 1992; Borst and Snellen, 2001).

Hilder et al. (2005), studied the action of the metformin $(2 \mathrm{mM})$ associated with insulin, during $24 \mathrm{~h}$ and observed that glucose uptake increased three-fold in the soleus muscle. This also occurred when only the metformin was managed, thus leading to the conclusion that the increase in glucose uptake in the evaluated muscle was independent of the insulin action, suggesting its action was at the after-receiver level. As metformin has an action related to the insulin metabolism, as well as an anabolic effect on the skeletal muscle, a possibly resultant anti-catabolic effect suggested with the metformin treatment in the immobilized muscles, since in the present study, the reduction of muscular weight inherent to disuse was minimized.

This study showed an important finding with the metformin treatment in immobilized muscle. However, further studies are necessary to assess the mechanisms of the metformin related to muscular disuse, because the increase in the glycogen stores is important in the rehabilitation process to maintain the skeletal muscle in better condition during the late stage of immobilization.

It can be concluded that the metformin treatment promoted a significant improvement in muscular glycogen stores in the skeletal muscle, and was effective in reestablishing the energy systems and minimizing the loss of the muscle weight under the joint immobilization condition. The metformin is applied for many therapeutic uses; however, the scarcity of studies on the use of this drug must be considered with the objective of minimizing the deleterious effects inherent to the muscle disuse. Further studies with diversified analyses that contemplate those of the present study are required.

\section{ACKNOWLEDGEMENTS}

The authors thank FAPESP (PROCESS: 05/60094-2) and CNPq for financial support. 


\section{RESUMO}

O objetivo deste estudo foi avaliar o conteúdo de glicogênio (GLI) da musculatura da pata posterior de ratos submetidos à imobilização articular, associado ou não ao tratamento com metformina (MET, 1,4 mg.ml -1) no período de sete dias. No grupo metformina, houve elevação significativa nas RG (65\% no sóleo - S, 30.5\% no gastrocnêmio branco - GB, $31.7 \%$ no gastrocnêmio vermelho $\mathrm{GV}, 44 \%$ no extensor longo dos dedos - EDL e de $77.4 \%$ no tibial anterior - TA). A imobilização reduziu significativamente as RG (S 31,6\%, GB $56,6 \%$, GV $39,1 \%$, ELD $41,7 \%$, TA $45,2 \%$ ) e peso (S 34,2\% e ELD 27\%), já no grupo imobilizado com metformina houve o aumento das RG de todos os músculos (S 177\%, GB 290\%, GV $172 \%$,EDL $47 \%$, TA $217 \%$ ), além de minimizar a perda de peso do S $(29,6 \%)$ e ELD $(27,8 \%)$.

\section{REFERENCES}

Albino, J.W.; Silva, C.A.; Taliari, K.R.S. and Cancelliero, K.M. (2004), Suplementação de glutamina melhora as reservas de glicogênio de músculos de ratos tratados com dexametasona. Rev. bras. educ. fís. esp., 18, 283-291,.

Aoki, M.S.; Lima, W.P.; Miyabara, E.H.; Gouveia, C.H. and Moriscot, A.S. (2004), Deleterious effects of immobilization upon rat skeletal muscle: role of creatine supplementation. Clin Nutr., 23, 1176.

Bailey, C.J. (2005), Treating insulin resistance in type 2 diabetes with metformin and thiazolidinediones. Diabetes Obes Metab.,7, 675-91.

Booth, F.W. and Seider, M.J. (1979), Recovery of skeletal muscle after 3 month. of hind limb immobilization in rats. J. Appl. Physiol. Physio., 47, 435-439.

Borst, S.E. and Snellen, H.G. (2001), Metformin, but not exercise training, increases insulin responsiveness in skeletal muscle of Sprague-Dawley rats. Life Sci., 69, 1497-507.

Cancelliero, K.M.; Barros, F.G.; Menezes, R.C.L.C. and Silva, C.A. (2004.), Efeito do CGT e do Clembuterol no perfil metabólico do músculo esquelético desnervado. Rev. ciências médicas., 13, 327-335.

Delfino, G.B.; Cancelliero, K. M.; Durigan, J.L.Q. and Silva, C. A. (2006), Efeito do sulfato de vanadil sobre o comprometimento metabólico. Rev Bras Med Esporte., Inpress

Dostou, J. and Gerich, J. (2001), Pathogenesis of type 2 diabetes mellitus. Exp Clin Endocrinol Diabetes., 109 2, 149-56.
Durigan, J.L.Q.; Cancelliero, K.M.; Dias, C.K.N.; Silva, C.A.; Guirro, R.R.J. and Polacow M.L. (2006), Efeitos da estimulação elétrica neuromuscular sobre o membro posterior imobilizado de ratos durante 15 dias: análises metabólicas e morfométricas. Rev Bras Fisioter., 10, 296-301.

Fushiki, T.; Kano, T.; Inoue, K. and Sugimoto, E. (1991), Decrease in muscle glucose transporter number in chronic physical inactivity in rats. Am J Physiol., 260, 403-10.

Glass, D.J. (2003), Signalling pathways that mediate skeletal muscle hypertrophy and atrophy. Nature Cell Biology., 5, 87-90

Guirro, R.R.J.; Silva, C.A.; Forti, F. and Cancelliero, K.M. (2004), Análise do músculo esquelético desnervado tratado com metformina e/ou estimulação elétrica de baixa frequência. Rev. bras. fisioter., $\mathbf{8}$, 21-27.

Henriksen, E.J.; Rodnick, K.J.; Mondon, C.E.; James, D.E. and Holloszy, J.O. (1991), Effect of denervation or unweighting on GLUT 4 protein in rat soleus muscle. J Apll Physiol., 70, 2322-2327.

Herbison, G.J.; Jaweed, M.M. and Ditunno, J.F. (1978), Muscle fiber atrophy after cast immobilization in the rat. Arch Phys Med Rehabil., 59, 305.

Hilder, T.L.; Baer, L.A.; Fuller, P.M.; Fuller, C.A.; Grindeland, R.E.; Wade, C.E. and Graves, L.M. (2005), Insulin-independent pathways mediating glucose uptake in hindlimb-suspended skeletal muscle. J Appl Physiol., 6, 2188.

Hirose, M.; Kaneki, M.; Sugita, H.; Yasuhara, S. and Martyn, J.A. (2000), Immobilization depresses insulin signaling in skeletal muscle. Am J Physiol Endocrinol Metab., 279, 1235-1241.

Howlett, H.C.S. and Bailey, C.J. (1999), A risk-benefit assessment of metformin in type 2 diabetes mellitus. Drug Saf., 20, 489-503.

Jaffe, L.F. and Stern, C.D. (1979), Strong electrical currents leave the primitive streak of chick embryos. Science, 206, 569-71.

Matthaei, S. and Greten, H. (1991), Evidence that metformin ameliorates cellular insulin-resistance by potentiating insulin-induced translocation of glucose transporters to the plasma membrane. Diabetes Metab., 17, 150-8.

Matthaei, S.; Stumvoll, M.; Kellerer, M. and Haring, H.U. (2000), Pathophysiology and pharmacological treatment of insulin resistance. Endocr Rev., 21, 585618.

McDougall, J.D.; Elder, G.C.B.; Sale, D.C. and Sutton, J.R. (1980), Effects of strength training and immobilization on human muscle fibers. Eur. J. Appl. Physiol., 43, 25-34.

Mitch, W. and Goldberg, A. (1996), The role of the ubiquitin-proteasome pathway.N. Engl. j. med., 335, 1905 . 
Musacchia, X.J.; Stefen, J.M. and Fell, R.D. (1988), Disuse atrophy of skeletal muscle: animal models. Exerc Sport Sci Ver., 16, 61-87.

National Research Council. (1996) Guide for the Care and Use of Laboratory Animals. Washington: National Academy Press.

Ploug, T.; Ohkuwa, T.; Handberg, A.; Vissing, J. and Galbo, H. (1995), Effect of immobilization on glucose transport and glucose transporter expression in rat skeletal muscle. Am J Physiol Endocrinol Metab., 268, 980-986.

Pryor, P.R.; Liu, C.S.H.; Clark, A.E.;Yand, J.; Holman, G.D. and Tosh, D. (2000), Chronic insulin effects on insulin signaling and GLUT4 endocutosisare reversed by metformin. Biochem.J., 348, 83-91.

Reardon, K.A.; Davis, J.; Kapsa, R.M.; Choong, P. and Byrne, E. (2001), Myostatin, insulin-like growth factor-1, and leukemia inhibitory factor are upregulated in chronic human disuse muscle atrophy. Muscle Nerve, 24, 893-9.

Reddi, A.S. and Jyothirmayi, G.N. (1992), Effect of chronic metformin treatment of hepatic and muscle glycogen metabolism in $\mathrm{KK}$ mice. Biochem Med Metab Biol., 47, 132.

Salvini, T.F. (2000), Plasticidade e adaptação dos músculos esqueléticos. In: MARQUES, A.P. Cadeias musculares. Um programa para ensinar avaliação fisioterapêutica global. MANOLE, São Paulo.

Schafer, G. (1983), Biguanides. A review of history, pharmacodynamics and therapy. Diabete Metab., 9, 148-63.
Silva, C.A; Guirro, R.R.J.; Polacow, M.L.O.; Cancelliero, K.M. and Durigan, J.L.Q. (2006), Proposal for rat hindlimb joint immobilization: orthosis with acrylic resin model. Braz J Med Biol Res., 39, 979-985.

Silva, C.A. and Cancelliero, K.M. (2006), Efeito da suplementação oral com creatina no músculo esquelético de membro imobilizado de ratos, Rev. Bras.Nutr. Clín., 21, 17-22.

Siu, L.O.; Russeau, J.C. and Taylor, A.W. (1970), Determination of glycogen in small tissue samples. $J$. Apll. Physiol., 28, 234-236.

Vanderborne, K.; Elliot, M.A.; Abdu, S.S.; Okereke, E.; Sgaffer, M.; Tahernia, D. and Esterhai, J.L. (1998), Longitudinal study of skeletal muscle adaptations during immobilization and rehabilitation. Muscle Nerve, 21, 1006-1012

Wilcox, G, (2005), Insulin and insulin resistance. Clin Biochem Rev., 26, 19-39.

Zarzhevsky, N.; Coleman, R.; Volpin, G.; Fuchs, D.; Stein, H. and Reznick, A.Z. (1999), Muscle recovery after immobilisation by external fixation. J Bone Joint Surg Br., 81, 90.

Zdanowicz, M. and Teichberg, S. (2003), Effects on insulin-like growth factor-1/binding protein-3 complex on muscle atrophy in rats. Exp Biol Med., 228, 9891-897.
Received: July 13, 2006; Revised: November 13, 2006; Accepted: January 21, 2008. 